\title{
PENGEMBANGAN LEMBAR KEGIATAN SISWA (LKS) BERBASIS PROBLEM BASED LEARNING (PBL) UNTUK MEMFASILITASI KEMAMPUAN PEMECAHAN MASALAH MATEMATIS SISWA DI SMA NEGERI 10 PEKANBARU
}

\author{
Nurzazili ${ }^{1}$, Ade Irma ${ }^{2}$, dan Depriwana Rahmi ${ }^{3}$ \\ 1,2.3 Jurusan Pendidikan Matematika, Universitas Islam Negeri Sultan Syarif Kasim Riau \\ Email penulis pertama: nurzazili5@gmail.com
}

\begin{abstract}
This research is based on the problem of the problem solving ability of mathematical problem and the limited of teaching materials used during the learning process. As an alternative to the problem, research is done by developing a teaching material in the form of Student Activity Sheet (LKS) based on Problem Based Learning (PBL). This study aims to generate Problem Based Learning (PBL) based LKS that is valid, practical and able to facilitate students' Mathematical Problem Solving abilities. This type of research is a development research using ADDIE (Analysis, Design, Development, Implementation and Evaluation). This research was conducted in SMP Negeri 10 Pekanbaru. Data types are quantitative and qualitative data. Data collection instruments are questionnaires and tests. Data analysis technique used is descriptive analysis of quantitative and qualitative descriptive analysis. The results showed that the quality of LKS developed was classified as very valid $(85.17 \%)$ and very practical $(87.72 \%$ for small groups and $89.35 \%$ for large groups). While $t$ hhitung value of 2.43 and t_tabel value at a significant level of 5\% of 1.99 then t_hitung > t_table or 2.43>1.99, so h_a accepted and h_0 rejected. This means that there is a significant difference in the ability of mathematical problem solving between experimental class students and control class students. It shows that LKS Mathematics Based Problem Based Learning has been valid, practical and can facilitate students' mathematical problem solving abilities.
\end{abstract}

Keywords: Worksheet, Problem Based Learning, Problem Solving Abiliy

\begin{abstract}
Abstrak
Penelitian ini didasarkan pada permasalahan rendahnya kemampuan pemecahan masalah matematis siswa dan masih terbatasnya bahan ajar yang digunakan saat proses pembelajaran. Sebagai alternatif dari permasalahan tersebut dilakukan penelitian dengan mengembangkan sebuah bahan ajar berupa Lembar Kegiatan Siswa (LKS) berbasis Problem Based Learning (PBL). Penelitian ini bertujuan untuk menghasilkan LKS berbasis Problem Based Learning (PBL) yang valid, praktis dan mampu memfasilitasi kemampuan Pemecahan Masalah Matematis Siswa. Jenis penelitian ini merupakan penelitian pengembangan dengan menggunakan model ADDIE (Analysis, Design, Development, Implementation dan Evaluation). Penelitian ini dilakukan di SMP Negeri 10 Pekanbaru. Jenis data berupa data kuantitatif dan kualitatif. Instrumen pengumpulan data berupa angket dan tes. Teknik analisis data yang digunakan adalah analisis deskriptif kuantitatif dan analisis deskriptif kualitatif. Hasil penelitian menunjukkan kualitas LKS yang dikembangkan tergolong dalam kategori sangat valid $(85.17 \%)$ dan sangat praktis $(87.72 \%$ untuk kelompok kecil dan $89.35 \%$ untuk kelompok besar). Sedangkan nilai $t_{\text {hitung }}$ sebesar 2,43 dan nilai $t_{\text {tabel }}$ pada taraf signifikan 5\% sebesar 1,99 maka $t_{\text {hitung }}>$ $t_{\text {tabel }}$ atau 2,43>1,99, sehingga $h_{a}$ diterima dan $h_{0}$ ditolak. Artinya terdapat perbedaan yang signifikan pada kemampuan pemecahan masalah matematika antara siswa kelas eksperimen dan siswa kelas kontrol. Hal tersebut menunjukkan bahwa LKS matematika berbasis Problem Based learning ini telah valid, praktis dan dapat memfasilitasi kemampuan pemecahan masalah matematis siswa.
\end{abstract}

Kata kunci: Lembar Kegiatan Siswa (LKS), Problem Based Learning, Kemampuan Pemecahan masalah Matematis

Matematika memiliki peranan yang sangat penting dalam kehidupan manusia serta bermanfaat bagi kehidupan sehari-hari. Matematika adalah ilmu dasar bagi dunia pendidikan karena 
matematika sangat mendukung untuk mempelajari ilmu-ilmu pengetahuan lainnya. Hal tersebut menunjukkan bahwa matematika sangat penting untuk dipelajari oleh siswa. Oleh karena itu, matematika perlu diajarkan kepada siswa agar dapat mengahadapi perkembangan ilmu pengetahuan dan diharapkan dapat menguasai serta memahami matematika tersebut.

Sejauh ini, pelajaran matematika masih dianggap sebagai mata pelajaran yang sukar dipahami oleh siswa. Salah satu alasannya karena matematika mempunyai objek yang bersifat abstrak yang tidak dapat dilihat bentuk nyatanya dan sulit dibayangankan oleh siswa secara langsung dan membutuhkan pemahaman konsep yang baik dalam memahami materi. Namun matematika tidak dapat dihindari oleh siswa karena diperlukan untuk memecahkan masalah sehari-hari. Setiap permasalahan yang dihadapi pasti memiliki penyelesaian, karena setiap kesulitan itu selalu menemukan kemudahan. Sebagaimana telah ditegaskan dalam Al-Qur'an bahwasanya orang-orang yang mampu menyelesaikan masalah/ kesulitanlah yang akan diberi kemudahan oleh Allah, seperti yang tercantum dalam Q.S. Al-Insyirah: 5-6 Artinya: karena Sesungguhnya sesudah kesulitan itu ada kemudahan. Sesungguhnya sesudah kesulitan itu ada kemudahan.(QS.AL-INSYIRAH:5-6)

Pemahaman matematika tidak hanya memfokuskan pada pemahaman konsep saja, namun juga harus merangsang pemecahan masalah. Pada dasarnya, akhir dari sebuah pembelajaran adalah menghasilkan siswa yang memiliki pengetahuan dan keterampilan dalam pemecahkan masalah yang dihadapi kelak di masyarakat. Pemecahan masalah dipandang sebagai suatu proses untuk menemukan kombinasi dari sejumlah aturan yang dapat diterapkan dalam upaya mengatasi situasi yang baru. Idealnya aktivitas pembelajaran tidak hanya difokuskan pada upaya mendapatkan pengetahuan sebanyak-banyaknya, melainkan juga bagaimana menggunakan segenap pengetahuan yang didapat untuk menghadapi situasi baru atau memecahkan masalah khusus yang ada kaitannya dengan bidang studi yang dipelajari.

Matematika memiliki tujuan pembelajaran yang membantu siswa agar dapat menggunakan matematika dan pola pikir matematika dalam kehidupan sehari-hari. Menurut peraturan menteri pendidikan dan kebudayaan RI No.58 Tahun 2014 bahwa tujuan pembelajaran matematika untuk sekolah Menengah Pertama (SMP) dan Madrasah Tsanawiyah yaitu agar siswa memiliki kemampuan dalam hal:

1. Memahami konsep matematika, menjelaskan keterkaitan antar konsep, dan menggunakan konsep maupun logaritma, secara luwes, akurat, efisien, dan tepat dalam pemecahan masalah.

2. Menggunakan pola sebagai dugaan dalam penyelesaian masalah, dan mampu membuat generalisasi berdasarkan fenomena atau data yang ada.

3. Menggunakan penalaran pada sifat, melakukan manipulasi matematika baik daam pemecahan masalah dalam konteks matematika maupun di luar matematika (kehidupan nyata, ilmu dan teknologi) yang meliputi kemampuan memahami masalah. 
4. Mengkomunikasikan gagasan, penalaran, serta mampu menyusun bukti matematika dengan menggunakan kalimat lengkap, simbol, tabel diagram atau media lain untuk memperjelas keadaan atau masalah.

5. Memiliki sikap menghargai keguruan matematika dalam kehidupan.

6. Memiliki sikap dan perilaku yang sesuai dengan nilai-nilai dalam matematika dan pembelajarannya

7. Melakukan kegiatan-kegiatan motorik yang menggunakan pengetahuan matematika

8. Menggunakan alat peraga sederhana maupun hasil teknologi untuk melakukan kegiatankegiatan matematika.

Pemecahan masalah akan menjadi hal yang sangat menentukan keberhasilan pendidikan matematika, sehingga pengintegrasian pemecahan masalah (problem solving) selama proses pembelajaran berlangsung hendaknya menjadi suatu keharusan. Ini berarti berhasil atau tidaknya seseorang dalam belajar matematika bisa dilihat dari kemampuan menyelesaikan atau memecahkan masalah yang dihadapi.

Matematika menuntut siswa mampu memecahkan masalah menjadi suatu hal yang perlu diperhatikan, terutama dalam mengembangkan bahan ajar sebagai penunjang kurikulum. Penggunaan dan pengembangan bahan ajar menjadi salah satu faktor penting dalam mencapai keberhasilan pembelajaran matematika yang dilihat dari kemampuan pemecahan masalah.

Berdasarkan hasil observasi dan wawancara dengan salah seorang guru matematika di SMP Negeri 10 Pekanbaru yaitu Ibu Hj.Yusli Herti, S.Pd. peneliti memperoleh informasi bahwa masih banyak siswa yang memiliki kemampuan pemecahan masalah matematika yang rendah. Hal tersebut terlihat bahwa siswa hanya menghafal rumus yang diberikan tanpa memahami konsep matematis dalam kegiatan pembelajaran. Permasalahan lain akan muncul pada saat siswa diberikan soal yang bervariatif. siswa yang hanya mengahafal rumus tanpa memahami konsep dasarnya maka akan kebingungan. Hal ini tentu tidak sesuai dengan tujuan pembelajaran matematika dalam pemecahan masalah matematika, kemampuan memahami masalah, merancang model matematika, menyelesaikan model, dan menafsirkan solusi yang diperoleh. Siswa tidak hanya menghafalkan rumus yang diberikan, akan tetapi siswa juga harus mampu menemukan konsep matematika yang tentunya dengan bimbingan dari guru.

Kemampuan pemecahan masalah matematika siswa masih berada pada taraf yang perlu dibantu dan dibimbing oleh guru. Namun, guru juga perlu menyadari posisinya di dalam suatu pembelajaran. Walaupun guru harus membantu dan membimbing siswa dalam menyelesaikan masalah matematika, peranan guru tidak dominan di dalam pembelajaran. Dalam mencapai kondisi pembelajaran yang demikian, maka diperlukan sumber belajar yang sesuai dan guru dapat membimbing untuk membantu siswa dalam proses pembelajaran matematika. Agar tercapainya tujuan pembelajaran matematika yang salah satunya adalah kemampuan pemecahan masalah 
matematis, maka perlu diberikan inovasi baru terhadap LKPD yang bertujuan untuk mengkonstruksi pengetahuan peserta didik.

Bahan ajar yang digunakan dengan tujuan memfasilitasi dan membantu siswa memahami materi pokok atau konsep dari sumber belajar dengan menggunakan bahasa yang mudah dipahami. Salah satu bahan ajar yang pernah digunakan siswa adalah Lembar Kegiatan Siswa (LKS). Berdasarkan hasil wawancara tersebut, peneliti juga memperoleh informasi bahwa LKS tidak digunakan lagi. Bahan ajar yang digunakan siswa hanya buku paket. LKS tidak digunakan lagi karena LKS yang pernah digunakan di SMP bukan hasil pengembangan dari guru, melainkan LKS yang diperoleh dari penerbit yang telah disediakan. LKS yang digunakan dalam proses pembelajaran di SMP belum menggunakan model pembelajaran, hanya sebagai sumber belajar bagi siswa dan belum mengarahkan siswa untuk mencapai kemampuan pemecahan masalah matematis. LKS yang digunakan memuat ringkasan materi yang terlalu singkat dan soal-soal latihan yang terlalu banyak, sehingga waktu tidak cukup untuk mengerjakan semua soal dan membahasnya di sekolah. Soal-soal latihan juga dipergunakan hanya untuk menguji penguasaan materi secara teoretis, sehingga siswa kurang terlibat langsung dalam pemecahan masalah. siswa langsung menerima informasi dari LKS tersebut tanpa berusaha untuk mengeksplorasi kemampuannya untuk dapat memperoleh suatu informasi.

Berdasarkan gejala-gejala tersebut, terlihat hal itu disebabkan oleh kemampuan pemecahan masalah yang masih minim. Kemampuan pemecahan masalah yang masih minim bukan sepenuhnya kesalahan dari siswa. Salah satu faktornya disebabkan oleh kurang efektifnya bahan ajar yang digunakan dalam menunjang proses pembelajaran. Dilihat dari hal tersebut, peneliti tertarik untuk melakukan penelitian pengembangan, yaitu pengembangan bahan ajar berupa LKS berbasis problem based learning. LKS merupakan suatu bahan ajar cetak berupa lembar-lembar kertas yang berisi materi, ringkasan, dan petunjuk-petunjuk pelaksanaan tugas pembelajaran yang harus dikerjakan siswa, yang mengacu pada kompetensi dasar yang harus dicapai. Selain itu, pemecahan masalah (Problem Based Learning) merupakan teknik yang cukup bagus untuk lebih memahami isi pelajaran, meningkatkan aktifitas pembelajaran, mentransfer pengetahuan mereka untuk memahami masalah dalam kehidupan nyata. Pembelajaran berbasis masalah (Problem Based Learning) melibatkan siswa dalam proses pembelajaran aktif dan kolaboratif, serta berpusat pada siswa sehingga mampu mengembangkan kemampuan pemecahan masalah secara mandiri. Maka dalam hal inilah yang mendorong peneliti untuk mengembangkan LKS ini menjadi sebuah penelitian yang berjudul: "Pengembangan Lembar Kegiatan Siswa (LKS) Berbasis Problem Based Learning (PBL) Untuk Memfasilitasi Kemampuan Pemecahan Masalah Matematis Siswa di Sekolah Menengah Pertama Negeri 10 Pekanbaru.

\section{METODE PENELITIAN}


Jenis penelitian yang dilakukan adalah metode penelitian dan pengembangan Research and Development ( $\mathrm{R} \& \mathrm{D})$ dengan model pengembangan yang peneliti gunakan ialah model ADDIE. ADDIE adalah singkatan dari analyze, design, development, implementation, dan evaluation. Peneliti memilih model ADDIE karena model ini adalah model yang langkah-langkah desain sistem pembelajarannya relatif sederhana dan mudah dipahami.Subjek dalam penelitian adalah siswa kelas VII SMP Negeri 10 Pekanbaru. Sedangkan objek penelitian ini adalah lembar kerja siswa matematika berbasis Problem Based Learing untuk memfasilitasi kemampuan pemecahan masalah matematis siswa. Waktu penelitian sudah dilaksanakan pada semester ganjil tahun ajaran 2017/2018.

Instrumen yang digunakan dalam penelitian ini adalah lembar validasi instrumen, instrumen validitas dan kepraktisan, tes kemampuan pemecahan masalah matematis. Teknik analisis data yang digunakan adalah analisis deskriptif kualitatif dan analisis deskriptif kuantitatif.

Jenis penelitian yang digunakan adalah quasi Eksperimen. Quasi eksperimen dengan desain nonequivalent control group design. Pada desain ini kelompok eksperimen maupun kelompok kontrol tidak dipilih secara random. Gambaran desain tersebut dapat dilihat pada Tabel III.1 berikut.

\section{TABEL III.1}

\section{Nonequivalent Control Group Design}

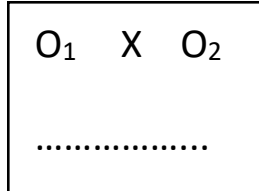

\section{Keterangan:}

$\mathrm{X}$ : Perlakuan yang berupa pembelajaran dengan menggunakan LKS berbasis Prolem Based Learning.

$\mathrm{O}_{1} \quad$ : Pretest kelas eksperimen

$\mathrm{O}_{2} \quad$ : Posttest kelas eksperimen

$\mathrm{O}_{3} \quad$ : Pretest kelas kontrol

$\mathrm{O}_{4} \quad$ : Posttest kelas kontrol

\section{PEMBAHASAN}

LKS berbasis Problem Based Learning pada materi Himpunan dinyatakan sangat valid pada uji validitas dengan persentase keidealan $77 \%$ oleh ahli teknologi pendidikan, dinyatakan sangat valid pada uji validitas dengan persentase keidealan $82 \%$ oleh ahli materi pembelajaran. Sehingga didapat rata-rata persentase keidealan $80 \%$ dengan kategori sangat valid. Hal ini menunjukkan bahwa LKS yang dikembangkan telah memenuhi syarat didaktik, syarat konstruksi, syarat teknis. Dengan demikian, LKS yang dikembangkan dapat digunakan dalam proses pembelajaran.

LKS berbasis model Problem Based Learning pada materi Himpunan termasuk kategori sangat praktis pada uji coba kelompok kecil dengan persentase keidealan 93.3\% dan kategori sangat praktis pula pada uji coba kelompok besar dengan persentase keidealan 90.5\%. Hal ini 
menunjukkan bahwa LKS yang dikembangkan dapat menarik minat siswa dan mudah digunakan dalam proses pembelajaran.

LKS matematika berbasis model Problem Based Learning pada materi Himpunan dinyatakan efektif. Hal ini ditunjukkan dari hasil uji t dengan $\mathrm{dk}=76$ dan taraf signifikan $5 \%$ atau 0,05 , maka diperoleh $t_{\text {tabel }}=1,99$ Diketahui bahwa $t_{\text {hitung }}>t_{\text {tabel }}$ yaitu $2,43>1,99$. Disimpulkan terdapat perbedaan pemahaman konsep matematika antara kelas eksperimen dengan kelas control setelah mengikuti pembelajaran menggunakan LKS matematika berbasis Problem Based Learning Rata-rata nilai tes siswa yang menggunakan LKS lebih tinggi yaitu 29,154 dibanding nilai rata-rata pembelajaran langsung yang rata-ratanya 26,077. Hal ini menunjukkan bahwa LKS sudah efektif serta dapat memfasilitasi kemampuan pemecahan masalah matematika siswa.

\section{KESIMPULAN DAN SARAN}

Kesimpulan:

1. LKS berbasis Problem Based Learning pada materi Himpunan dinyatakan sangat valid pada uji validitas dengan persentase keidealan $77 \%$ oleh ahli teknologi pendidikan, dinyatakan sangat valid pada uji validitas dengan persentase keidealan $82 \%$ oleh ahli materi pembelajaran. Sehingga didapat rata-rata persentase keidealan $80 \%$ dengan kategori sangat valid. Hal ini menunjukkan bahwa LKS yang dikembangkan telah memenuhi syarat didaktik, syarat konstruksi, syarat teknis. Dengan demikian, LKS yang dikembangkan dapat digunakan dalam proses pembelajaran.

2. LKS berbasis model Problem Based Learning pada materi Himpunan termasuk kategori sangat praktis pada uji coba kelompok kecil dengan persentase keidealan 93.3\% dan kategori sangat praktis pula pada uji coba kelompok besar dengan persentase keidealan 90.5\%. Hal ini menunjukkan bahwa LKS yang dikembangkan dapat menarik minat siswa dan mudah digunakan dalam proses pembelajaran.

3. LKS matematika berbasis model Problem Based Learning pada materi Himpunan dinyatakan efektif. Hal ini ditunjukkan dari hasil uji $\mathrm{t}$ dengan $\mathrm{dk}=76$ dan taraf signifikan 5\% atau 0,05, maka diperoleh $t_{\text {tabel }}=1,99$ Diketahui bahwa $t_{\text {hitung }}>t_{\text {tabel }}$ yaitu 2,43 $>1,99$. Disimpulkan terdapat perbedaan pemahaman konsep matematika antara kelas eksperimen dengan kelas control setelah mengikuti pembelajaran menggunakan LKS matematika berbasis Problem Based Learning Rata-rata nilai tes siswa yang menggunakan LKS lebih tinggi yaitu 29,154 dibanding nilai rata-rata pembelajaran langsung yang rata-ratanya 26,077. Hal ini menunjukkan bahwa LKS sudah efektif serta dapat memfasilitasi kemampuan pemecahan masalah matematika siswa.

Berdasarkan penelitian yang telah dilakukan, peneliti menyarankan hal-hal sebagai berikut:1)

Saran Pemanfaatan yaitu peneliti menyarankan agar a) LKS ini digunakan dalam pembelajaran Himpunan kelas VII karena telah diuji cobakan dengan hasil yang baik. b) Penggunaan LKS berbasis Problem Based Learning pada materi Himpunan ini dikolaborasikan dengan pembelajaran 
matematika yang menarik lainnya agar pembelajaran menjadi lebih bervariatif. c) Kepada guru hendaknya menyarankan siswanya untuk belajar di rumah terlebih dahulu menggunakan LKS matematika dengan Problem Based Learning ini, supaya siswa lebih mudah memahami materi yang akan dipelajari di kelas. 2) Saran Pengembangan Produk yaitu peneliti menyarankan agar a) LKS berbasis Problem Based Learning ini dikembangkan lebih lanjut dengan menggunakan 2 kelas atau lebih kelas eksperimen dan pembanding, agar kualitas LKS ini benar-benar teruji dalam hal pemanfaatannya. b) Peneliti menyarankan bagi peneliti selanjutnya agar mengembangkan LKS berbasis Problem Based Learning pada materi yang berbeda terhadap kemampuan pemecahan masalah matematika. Sehingga LKS yang dikembangkan dapat dijadikan sebagai bahan ajar yang dapat digunakan dalam proses pembelajaran.

\section{DAFTAR PUSTAKA}

Astuti, A., \& Sari, N. (2017). PENGEMBANGAN LEMBAR KERJA SISWA (LKS) PADA MATA PELAJARAN MATEMATIKA SISWA KELAS X SMA. Jurnal Cendekia : Jurnal Pendidikan $\begin{array}{llll}\text { Matematika, } & 1(2), & \text { Retrieved }\end{array}$ from http://journal.stkiptam.ac.id/index.php/cendekia/article/view/224

Anas Sudijono. 2008. Pengantar Evaluasi Pendidikan Jakarta: PT Raja Grafindo Persada.

Endang, Mulyatiningsih. 2012. Metode Penelitian Terapan Bidang Pendidikan. Bandung: Alfabeta.

Endang, Widjajanti, "Kualitas Lembar Kerja Siswa", Makalah ini disampaikan dalam Kegiatan Pengabdian pada Masyarakat dengan judul: Pelatihan Penyusunan LKS Mata Pelajaran Kimia Berdasarkan Kurikulum Tingkat Satuan Pendidikan Bagi Guru SMK/MAK di Ruang Sidang FMIPA UNY

Fadjar, shadiq. 2004. Pemecahan Masalah, Penalaran Dan Komunikasi Matematika. Yogyakarta: Depdiknas.

Hamdani. 2011. Strategi Belajar Mengajar. Bandung: Pustaka Setia.

Hartono. 2010. Analisis Item Instrumen. Pekanbaru: Zanafa Publising 2008. Statistik Untuk Penelitian. Pekanbaru: Zanafa Publishing.

Hasnan, Aufika. pengembangan perangkat pembelajaran matematika berbasis Problem Based Learning (PBL) pada materi perbandingan dan skala untuk meningkatkan kemampuan pemecahan masalah siswa SMP kelas VII (skripsi jurusan matematika: Fakultas Matematika dan Ilmu Pengetahuan Alam universitas negeri yogyakarta, 2015).

Herman, Hudojo. 1990. Strategi Pembelajaran Matematika. Malang: IKIP Malang.

I Made Tegeh dan I Made Kirna, "Pengembangan Bahan Ajar Metode Penelitian Pendidikan dengan ADDIE Model", Dosen Jurusan Teknologi Pendidikan FIP Undiksha dan Dosen Jurusan Pendidikan Kimia FMIPA Undiksha, ISSN 1829-5282.

Kemendikbud. "Peraturan Menteri Pendidikan Dan Kebudayaan Republik Indonesia Nomor. 58 Tahun 2014. Tentang matematika SMP. Jakarta. 
Pengembangan Lembar Kegiatan Siswa (LKS) Berbasisproblem Based Learning (PBL) Untuk Memfasilitasikemampuan Pemecahan Masalah Matematissiswa Di SMA Negeri 10 Pekanbaru, Nurzazili, Ade Irma, Depriwana Rahmi

Majid, Abdul dan Rochman, Chaerul. 2014. Pendekatan Ilmiah dalam Implementasi Kurikulum 2013. Bandung: Rosdakarya.

Mas'ud Zein. 2011. Evaluasi Pembelajaran Analisis Soal Essay. Pekanbaru: UIN Suska Riau.

Noviarni. 2014. Perencanaan Pembelajaran Matematika dan Aplikasinya. Pekanbaru: Benteng Media.

Paul Edgen dan Don Kauchak. 2012. Strategi dan Metode Pembelajaran. Jakarta: PT. Indeks.

Prastowo, Andi. 2013. Panduan Kreatif Membuat Bahan Ajar Inovatif. Jogjakarta: DIVA Pers.

Pribadi, Benny A.. 2009. Model Desain Sistem Pembelajaran. Jakarta: Dian Rakyat.

Putra, Sitiatava Rizema. 2013. Desain Belajar Mengajar Kreatif Berbasis Sains Yogyakarta: DIVA Press Cet 1.

Riduwan. 2012. Belajar Mudah Penelitian Guru-Karyawan dan Pemula. Bandung: Alfabeta.

Rosita, Neneng Tita. 2013. Seminar Nasional Matematika dan Pendidikan Matematika. FMIPA UNY Yogyakarta.

Sheila, Rabila Adarsah. pengembangan modul pembelajaran berbasis problem based learning untuk memfasilitasi kemampuan pemecahahan masalah Matematis siswa (skripsi jurusan matematika: Fakultas Tarbiyah Dan Keguruan Pendidikan Matematika, 2016).

Siska Juliza, Pengembangan Lembar Kerja Siswa (LKS) Matematika Berbasis Problem Based Learning pada Materi Operasi Aljabar di Kelas VIII SMP."(Jurnal FKIP Universitas Jambi.2015).

Sugiyono. 2012. Statistik Untuk Peenelitian. Bandung: Alfabeta.

2013. Metode Penelitian Kuantitatif, Kualitatif dan R\&D. Bandung: Alfabeta.

2016. Metodologi Penelitian Pendidikan. Bandung: Alfabeta.

.2013Metode Penelitian Pendidikan Pendekatan Kuantitatif, Kualitatif, dan R\&D, Bandung:

Alfabeta.

Suprihatiningrum, Jamil. 2012. Strategi Pembelajaran. Jakarta: Ar-Ruzz Media.

Suyadi. 2013. Strategi Pembelajaran Pendidikan Karakter. Bandung : PT. Remaja Rosdakarya.

Tim Penyusun. 1990. Kamus Besar Bahasa Indonesia. Jakarta: Balai Pustaka.

Trianto. 2010. Model Pembelajaran Terpadu. Jakarta: Bumi Aksara

Wena, Made. 2011. Strategi Pembelajaran Inovatif Kontemporer. Jakarta: Bumi Aksara.

Zakaria, Effendi. 2007. Trend Pengajaran dan Pembelajaran Matematika. Kuala Lumpur: Loh Print SDN, BHD.

Zulfah, Z. (2017). TAHAP PRELIMINARY RESEARCH PENGEMBANGAN LKPD BERBASIS PBL UNTUK MATERI MATEMATIKA SEMESTER 1 KELAS VIII SMP. Jurnal Cendekia : $\begin{array}{lllll}\text { Jurnal Pendidikan } \quad \text { Matematika, } & \text { 1(2), }\end{array}$ from http://journal.stkiptam.ac.id/index.php/cendekia/article/view/184 